\title{
Reproductive performance of heifers of different weight classes in the first and second mating
}

\section{Desempenho reprodutivo de novilhas de distintas classes de peso no primeiro e segundo acasalamento}

\author{
Rangel Fernandes Pacheco'*; Ivan Luiz Brondani²; Dari Celestino Alves Filho²; \\ Jonatas Cattelam³; Andrei Retamoso Mayer'; Ana Paula Machado Martini'; \\ Gilmar Cardoso dos Santos ${ }^{5}$; Daniele Borchate ${ }^{5}$; João Restle ${ }^{6}$
}

\begin{abstract}
The objective of this study was to evaluate the effect of live weight at first mating on reproductive performance in the first and second reproductive years. For that purpose, the reproductive history of 221 heifers mated for the first time between the years of 2003 and 2012 was evaluated. Heifers were grouped into three weight classes at the age of 24 months: 50-59.9\% (55\%), 60-69.9\% (65\%), and 70-80\% $(75 \%)$. The pregnancy rate in the first reproductive year in heifers from weight classes $55 \%, 65 \%$, and $75 \%$ was $38.0 \%, 56.4 \%$, and $69.0 \%$, respectively. The pregnancy rate in the second reproductive year was not affected by weight at first mating $(\mathrm{p}>0.05)$ and corresponded to $41.6 \% ; 42.1 \%$, and $50.4 \%$ in the three weight classes, respectively. The weight class of heifers before mating at the age of 24 months affected reproductive performance at first mating but did not increase the pregnancy rate in the second reproductive year.
\end{abstract}

Key words: Heifer development. Desired body weight. First mating. First calving.

\section{Resumo}

Objetivou-se avaliar o efeito do peso vivo ao primeiro acasalamento de novilhas sobre o desempenho reprodutivo na primeira e segunda monta. Para isso, foi avaliado o histórico reprodutivo de 221 novilhas de corte acasaladas pela primeira vez entre os anos de 2003 até 2012. As novilhas foram agrupadas em três classes de peso vivo aos 24 meses de idade, sendo eles: entre 50 a $59,9 \%$ do peso adulto (55\%); de 60 a $69,9 \%$ do peso adulto $(65 \%)$ e entre 70 a $80 \%$ do peso adulto $(75 \%)$. A taxa de prenhez no primeiro ano reprodutivo foi de $38,0 \% ; 56,4 \%$ e $69,0 \%$ às acasaladas com faixa de peso de $55 \%, 65 \%$ e $75 \%$; respectivamente. A taxa de prenhez no segundo ano reprodutivo não sofreu efeito da classe de peso ao primeiro acasalamento $(p>0,05)$ com valores de $41,6 \% ; 42,1 \%$ e $50,4 \%$. A classe de peso antes do acasalamento de novilhas aos dois anos de idade interfere no desempenho reprodutivo na primeira monta, mas não resulta em aumento na taxa de prenhez no segundo ano reprodutivo.

1 Prof. Dr., Instituto Federal de Santa Catarina, IFSC, Canoinhas, SC, Brasil. E-mail: rangel.pacheco@ifsc.edu.br

2 Profs. Drs., Departamento de Zootecnia, Universidade Federal de Santa Maria, UFSM, Santa Maria, RS, Brasil. E-mail: ivanbrondani@gmail.com; darialvesfilho@hotmail.com

3 Prof. Dr., Universidade Federal da Fronteira Sul, UFFS, Realeza, PR, Brasil. E-mail: jonatascattelam@yahoo.com.br

4 Prof. Dr., Instituto de Desenvolvimento Educacional do Alto Uruguai, IDEAU, Passo Fundo, RS, Brasil. E-mail: andreirm@bol. com.br

5 Discentes, Programa de Pós-Graduação em Zootecnia, Universidade Federal de Santa Maria, UFSM, Santa Maria, RS, Brasil. E-mail: anapaulamartini@zootecnista.com.br; cardoso-gilmar@bol.com.br; danieleborchate@gmail.com

6 Prof. Dr., Departamento de Zootecnia, Universidade Federal de Goiás, UFG, Goiânia, GO, Brasil. E-mail:jorestle@terra.com.br

" Author for correspondence 
Palavras-chave: Desenvolvimento de novilhas. Peso corporal desejado. Primeiro acasalamento. Primeiro parto.

\section{Introduction}

Over the past 50 years, many studies have demonstrated an inverse relationship between the post-weaning growth rate of calves and age at puberty. The age at puberty affects the pregnancy rate because the onset of puberty is genetically determined by several factors, especially live weight (LW) (WILTBANK et al., 1966).

Since then, management protocols have been developed to establish heifers' target weight at first mating, and most of the protocols adopted until the 1990s have considered $60-65 \%$ of adult weight for each animal breed as the ideal weight range for breeding herds (PATTERSON et al., 1992). However, recent studies conducted in the United States and Canada using intensive production systems suggest that this recommendation should be re-evaluated because of genetic changes in herds (FUNSTON; DEUTSCHER, 2004).

In Brazil, some characteristics of production systems, including the genetic composition of the herd, the nutritional quality of the feed, and low rates of in the second reproductive year, support the recommendation of increasing weight gain at first mating for heifers. Higher weight gain close to the mating period reduces the age at puberty and constitutes a promising strategy for increasing pregnancy rates in zebu herds (BARCELLOS et al., 2014). In addition, the increase in heifer weight in the second reproductive year is relevant because of the return of postpartum estrus (CUSHMAN et al., 2013).

The analysis of the effect weight at first mating on the reproductive performance of heifers in the first and second reproductive years for breeding herds under pasture conditions in regions of subtropical climate in Brazil is essential for decision-making about the best management strategies for heifers.
Therefore, the objective of this study is to evaluate the reproductive performance of heifers of different LW classes at first mating in the first and second reproductive years.

\section{Materials and Methods}

The study was carried out at the Cattle Breeding Laboratory (Laboratório de Bovinocultura de Corte-LBC) of the Animal Science Department of the Federal University of Santa Maria in the municipality of Santa Maria, Rio Grande do Sul, Brazil. The municipality is located in the central depression region (altitude of $153 \mathrm{~m}$ and latitude of $30^{\circ} \mathrm{S}$ ) of Rio Grande do Sul. The prevailing climate of the region is humid subtropical according to Köppen's classification. The mean annual temperature varies from 14.3 to $25.2{ }^{\circ} \mathrm{C}$, with a minimum of $9.7^{\circ} \mathrm{C}$ in August and maximum of 29.9 ${ }^{\circ} \mathrm{C}$ in January. The mean annual relative air humidity is $73 \%$, and precipitation is $1650.9 \mathrm{~mm}$ (ALVARES et al., 2013).

\section{Study site}

Data were obtained from animals from the experimental flock used in the project of rotational crossbreeding between Charolais and Nelore cattle, started in 1984, whose objective was to evaluate the reproductive and productive performance of cows and the characteristics of the carcass and meat of beef cattle. The males were slaughtered, and females were mated for the first time at the age of 24 months. The average number of breeding heifers in the herd was 280. The animals were reared on a natural pasture with a stocking rate of $350 \mathrm{~kg} \mathrm{LW} \mathrm{ha}^{-1}$, annual ingress of approximately 50 heifers, and average pregnancy rate of $65 \%$. All heifers that entered the herd were from the same experimental flock. 


\section{Nutritional management}

The objective of the nutritional management of heifers was to mate heifers at the age of 24 months. For this purpose, after weaning (age of 60 to 90 days), the heifers were allowed to graze in a warm-season pasture with concentrated protein supplementation until the beginning of the winter period and then were transferred to cold-season pasture without supplementation. In the second summer and winter, nutritional management was performed according to the cost of animal maintenance in the cultivated pastures, body weight, and body condition score (BCS), and most of the animals were kept in natural pastures. Pregnant cows were maintained in natural pastures together with the other breeding cows. The supplemented minerals were sodium chloride (common salt) and dicalcium phosphate and were offered at libitum in troughs near pasture pickets. The control of endo- and ectoparasites and vaccinations were carried out in all cows according to need and/or sanitary guidelines.

The grass species used in animal feeding in the study period were elephant grass (Pennisetum purpureum), millet (Pennisetum americanum (L.). Leeke), or Tifton 85 (Cynodon spp. cv. Tifton 85) in spring/summer, and oats (Avena strigosa Schreb.) and/or ryegrass (Lolium multiflorum Lam.) in the winter/spring. Natural pastures were highly infested with anonni-2 grass (Eragrostis plana Ness).

\section{Reproductive management}

The reproductive management of the herd consisted of maintaining the animals in natural pastures, with an insemination period of approximately 45 days (December 1 to January 15) and a further 45 days of maintenance of breeding bulls in the pasture (ratio of one breeding bull for $30-40$ cows). The semen used for insemination was obtained from commercial insemination centers in Brazil using six bulls of each breed (Charolais or Nellore). The criterion for selecting breeding bulls considered the commercial value of each dose of semen and the expected progeny difference for birth weight and weaning. The choice of semen at the time of insemination was random, and the bull breed was chosen according to the genetic composition of the cow.

The calving season was from September 15 to December 15. After birth, each calf was ear-tagged, weighed, and subjected to sanitary management with vaccination. Cows were weighed and assigned a 5-point BCS according to the amount of body fat, as follows: 1 , very lean; 2 , lean; 3 , average; 4 , fat; and 5 , very fat.

\section{Building database}

The calving date and weight, LW at weaning, LW at the age of 7, 12, 18, and 24 months, LW at the end of mating, and LW at calving were recorded. Each LW information was adjusted to the age and difference (in days) between weighings. Data on the mean daily LW gain at age 7 to 18 months, age 18 to 24 months, and age 24 months to the end of the first mating; LW gain from calving to weaning, and LW gain from weaning until the end of the second mating were obtained by the difference in weight between these periods and the number of days between weighings. The weight difference from the age of 24 months to first calving was calculated. The calving date was used to determine the subperiod of calving, which corresponded to the percentage of cows that calved in the first half of the calving season. This parameter also served to calculate the interval from the beginning of mating to pregnancy, from calving to the beginning of mating, and from calving to the end of mating. The weights of calves were also recorded at calving and weaning. These data were recorded in Excel spreadsheets and later stored in a database at the LBC headquarter.

The inclusion criteria were cows that (1) mated for the first time between 2003 and 2012; (2) had a mean LW (adjusted to 24 months of age) of $50-80 \%$ of the weight of adult cows; and (3) were of second, third, fourth, fifth, or sixth generation of the genetic 
cross between Charolais and Nelore. None of the heifers that mated in the year 2010 met the three inclusion criteria. None of the heifers from the sixth generation with a predominance of Charolais breed met the inclusion criteria. With respect to the second reproductive year, only heifers that had calved at 36 months of age and calves subjected to early weaning (average of 75 days) were included in the analysis. The weight of adult cows with a BCS score of 4 was $500 \mathrm{~kg}$. For this calculation, the average LW at slaughter of 517 cows from the same herd and of the same genotype of heifers slaughtered in 2003-2013 was considered.

\section{Experimental design}

The treatments were initiated by grouping the heifers according to weight classes at 24 months of age, resulting in the formation of three adult LW classes: $50-60 \%(55 \%), 60-70 \%$ (65\%), and 70$80 \%(75 \%)$.

The distribution of heifers by genetic group, year of mating, and adult weight by genotype is presented in Table 1.

\section{Statistical analysis}

Statistical analysis was performed using the general linear model procedure of SAS software version 9.2. Data were tested for normality using the Kolmogorov-Smirnov test. For the daily average LW gain from calving to weaning, the square root was transformed to obtain a normal distribution. The data were subjected to detection of outliers using Student's statistic, and values above 2 and below -2 were excluded. The data were also subjected to analysis of variance using the $F$ test and a test of comparison of means (Student's $t$-test) at a level of significance of $5 \%$.

The mathematical model used for the analysis of variance was:

$$
\mathrm{Y}_{\mathrm{ijklm}}=\mu+\text { Year }_{\mathrm{i}}+\mathrm{JD}_{\mathrm{j}}+\mathrm{P} 205_{\mathrm{k}}+\mathrm{T}_{1}+\left[\mathrm{GEN}_{\mathrm{m}}+\right.
$$
$\left.\mathrm{GG}_{\mathrm{n}}(\mathrm{GEN})_{\mathrm{m}}\right]+\mathrm{e}_{\mathrm{ijklm}}$

where $Y_{i j k l m}$ is the dependent variables; $\mu$ is the mean of all observations; Year $_{i}$ is the year of mating of each heifer (from 2003 to 2012); $\mathrm{JD}_{\mathrm{j}}$ is the Julian date of birth of each heifer; $\mathrm{P} 205_{\mathrm{k}}$ is the heifer's LW adjusted to 205 days; $T_{1}$ is treatment; $\mathrm{GEN}_{\mathrm{m}}$ is the animal generation (second to sixth); $\mathrm{GG}_{\mathrm{n}}(\mathrm{GEN})_{\mathrm{m}}$ is the genetic group of each generation $(n=2, \ldots$. $6) ; \mathrm{e}_{\mathrm{ijklm}}$ is the random error associated with each observation, NID $(0, \sigma 2)$.

Table 1. Distribution of heifers according to the year of mating and genetic group.

\begin{tabular}{|c|c|c|c|c|c|c|c|c|c|c|}
\hline \multirow[t]{2}{*}{ LW group } & \multicolumn{10}{|c|}{ Year of mating } \\
\hline & 2003 & 2004 & 2005 & 2006 & 2007 & 2008 & 2009 & 2011 & 2012 & Total \\
\hline $55 \%$ & 10 & 15 & 10 & 0 & 14 & 17 & 0 & 12 & 4 & 85 \\
\hline $65 \%$ & 25 & 13 & 22 & 3 & 17 & 12 & 2 & 0 & 3 & 97 \\
\hline $75 \%$ & 12 & 6 & 5 & 9 & 1 & 2 & 4 & 0 & 3 & 39 \\
\hline \multirow[t]{4}{*}{ Total } & 47 & 34 & 37 & 12 & 32 & 31 & 6 & 12 & 10 & 221 \\
\hline & \multicolumn{10}{|c|}{ Genetic group } \\
\hline & $3 / 4 \mathrm{C}$ & $3 / 4 \mathrm{~N}$ & $5 / 8 \mathrm{C}$ & $5 / 8 \mathrm{~N}$ & $11 / 16 \mathrm{C}$ & $11 / 16 \mathrm{~N}$ & $21 / 32 \mathrm{C}$ & $21 / 32 \mathrm{~N}$ & $43 / 64 \mathrm{~N}$ & \\
\hline & $1 / 4 \mathrm{~N}$ & $1 / 4 \mathrm{C}$ & $3 / 8 \mathrm{~N}$ & $3 / 8 \mathrm{C}$ & $5 / 16 \mathrm{~N}$ & $5 / 16 \mathrm{C}$ & $11 / 16 \mathrm{~N}$ & $11 / 16 \mathrm{C}$ & $21 / 64 \mathrm{C}$ & \\
\hline \multirow[t]{2}{*}{ LW group } & \multicolumn{10}{|c|}{ Generation $(\mathrm{G})$} \\
\hline & $\mathrm{G} 2$ & $\mathrm{G} 2$ & G3 & G3 & G4 $\quad \mathrm{G}$ & G4 G5 & 5 & 5 & 6 & \\
\hline $55 \%$ & 4 & 2 & 5 & 6 & 22 & 13 & 11 & 19 & 3 & \\
\hline
\end{tabular}


continuation

\begin{tabular}{lccccccccc}
$65 \%$ & 6 & 3 & 14 & 18 & 25 & 9 & 6 & 13 & 3 \\
$75 \%$ & 5 & 2 & 3 & 5 & 4 & 7 & 4 & 8 & 1 \\
Total & 15 & 7 & 22 & 29 & 51 & 29 & 21 & 40 & 7 \\
\hline $\mathrm{LW}, \mathrm{kg}$ & 480 & 455 & 500 & 490 & 510 & 500 & 505 & 495 & 500 \\
\hline
\end{tabular}

$\mathrm{C}=$ Charolais; $\mathrm{N}=$ Nellore; $\mathrm{LW}=$ Live weight of adult cows.

\section{Results and Discussion}

The daily average LW gain before mating, body weight, $\mathrm{BCS}$, and calving rate varied according to the LW class (Table 2). There was higher LW gain from the age of 7 to 18 months for heifers from the two largest LW classes $\left(65 \%, 0.38 \mathrm{~kg} \mathrm{day}^{-1}\right.$; and $\left.75 \%, 0.42 \mathrm{~kg} \mathrm{dia}^{-1}\right)$ relative to heifers from LW class $55 \%\left(0.32 \mathrm{~kg} \mathrm{day}^{-1}\right)$. Roberts et al. (2009a) found that food restriction at age 8 to 12 months decreased the percentage of pubertal heifers at age 14 months $(60 \%$ vs. $68 \%)$ and the pregnancy rate $(48 \%$ vs. $57 \%)$.

Table 2. Performance of heifers from the age of seven months to the end of the first mating according to weight.

\begin{tabular}{lcccc}
\hline \multirow{2}{*}{\multicolumn{1}{c}{ Variables }} & \multicolumn{3}{c}{ Live weight class } & \multirow{2}{*}{$P$} \\
\cline { 2 - 4 } & $55 \%$ & $65 \%$ & $75 \%$ & \\
\hline ADG from 7 to 18 months, kg & $0.32 \pm 0.01 \mathrm{~b}$ & $0.38 \pm 0.01^{\mathrm{a}}$ & $0.42 \pm 0.02^{\mathrm{a}}$ & $<0.0001$ \\
ADG from 18 to 24 months, kg & $0.14 \pm 0.02 \mathrm{c}$ & $0.22 \pm 0.02 \mathrm{~b}$ & $0.43 \pm 0.03 \mathrm{a}$ & $<0.0001$ \\
Weight at 24 months, kg & $278.6 \pm 1.9 \mathrm{c}$ & $315.2 \pm 1.8 \mathrm{~b}$ & $362.5 \pm 2.7 \mathrm{a}$ & $<0.0001$ \\
BCS at 24 months, points & $2.74 \pm 0.06 \mathrm{~b}$ & $2.95 \pm 0.07 \mathrm{a}$ & $3.13 \pm 0.07 \mathrm{a}$ & 0.0003 \\
ADG from the age of 24 months to the end of mating, kg & $0.322 \pm 0.04$ & $0.232 \pm 0.03$ & $0.270 \pm 0.05$ & 0.0978 \\
LW at the end of mating, kg & $332.8 \pm 5.6 \mathrm{c}$ & $362.7 \pm 5.0 \mathrm{~b}$ & $419.8 \pm 7.6 \mathrm{a}$ & $<0.0001$ \\
BCS at the end of mating, points & $2.71 \pm 0.03 \mathrm{~b}$ & $2.78 \pm 0.02 \mathrm{ab}$ & $2.84 \pm 0.04 \mathrm{a}$ & 0.0230 \\
Pregnancy rate, $\%$ & $38.0 \pm 6.8 \mathrm{c}$ & $56.4 \pm 6.2 \mathrm{~b}$ & $69.0 \pm 8.6 \mathrm{a}$ & 0.0087 \\
\hline
\end{tabular}

ADG, average daily live gain; BCS, body condition score; LW, live weight.

a, b, c different lowercase letters on the same line indicate significant differences at a level of significance of $5 \%$.

The differences in performance between the LW classes were higher at the age 18-24 months. LW gain in heifers from LW class $55 \%(0.14 \mathrm{~kg}$ day$\left.{ }^{1}\right)$ was lower than that in heifers from LW class $65 \%\left(0.22 \mathrm{~kg} \mathrm{day}^{-1}\right)$, which in turn was lower than that of animals from LW class $75 \%\left(0.43 \mathrm{~kg}^{-}\right.$day $^{-}$ $\left.{ }^{1}\right)$. This result helps understand the reproductive performance of heifers at first mating because the rate of LW gain at this stage of development affects the physiological factors that trigger the onset of reproduction and age at puberty (GASSER et al., 2006; COOKE et al., 2008; ALLEN et al., 2012;
EBORN et al., 2013; BARCELLOS et al., 2014; FARIAS et al., 2018).

The higher BCS at 24 months of age in heifers from LW classes 65\% (2.95 points) and 75\% (3.13 points) relative to those from LW class 55\% (2.74 points) is a consequence of different LW gain rates in the growth phase (ADG from 7 to 18 months and from 18 to 24 months). Although heifers from classes $55 \%$ and $65 \%$ achieved LW values considered minimal at first mating, Wiltbank et al. (1966) and Funston and Deutscher (2004) indicated that the BCS values were below the threshold at first 
mating (3.0 points). The BCS results are directly related to the calving rate results in these two LC classes, as will be discussed later.

The average daily LW gain from the age of 24 months to the end of mating was similar between the LW classes $(\mathrm{p}=0.0978)$. LW gains may be higher in heifers from LW class $55 \%$ because of their lower LW gain in a previous developmental phase (ADG from 18 to 24 months). Compensatory weight gains are common in extensive production systems and lead to an increase in the pregnancy rate (FUNSTON; LARSON, 2011; ENDECOTT et al., 2013). This result may be associated with the low nutritional quality of natural pastures and the high infestation of pastures with Eragrostis plana Ness. This grass species is expanding rapidly in Brazil (CICCONET et al., 2015) and may compromise the development of breeding herds (SOUZA et al., 2012).

LW at the end of mating followed the same trend of LW at 24 months of age and was different between the three weight classes, corresponding to $66 \%$, $72 \%$, and $84 \%$ in LW classes $55 \%, 65 \%$, and $75 \%$, respectively. Increased weight at the end of mating, in addition to reflecting better animal performance in the mating phase, reduces the need for weight gain in later stages to ensure adequate weight at calving. Following the weight recommendations at the end of the first mating, only heifers from LW class $75 \%$ reached the ideal weight in this production phase, with a minimum adult weight of $75 \%$.

The BCS at the end of mating was higher in heifers from LW class 75\% (2.84 points) than in those from LW class 55\% (2.71 points), and these two values were similar to that of animals from LW class $65 \%$ (2.78 points). This difference was due to the low performance of heifers from LW class 55\% during the growth phase and the limited feeding of cows in natural pastures during mating. This parameter can be improved by increasing animal weight and is one of the reasons for mating heifers with $>65 \%$ of adult weight. However, cows from LW class $75 \%$ did not show increases in this variable at the end of the first mating compared with those from LW class $65 \%$, evidencing that animals with larger LW at first mating reached their maximum genetic potential under the evaluated environmental conditions. Increases $>75 \%$ of adult weight can be obtained by improving natural and cultivated pastures and supplementation. It is also appropriate to consider the genetic composition of the herd of the present study, Charolais and Nelore, which are breeds with late fat deposition compared to British breeds (NRC, 1996), which are widely used in research studies worldwide.

The calving rate was $38 \%, 56 \%$, and $69 \%$ in heifers from LW classes $55 \%, 65 \%$, and $75 \%$; respectively. These results followed the variations in ADG from 18 to 24 months and from 24 months to the end of mating and were higher for animals from LW classes $65 \%$ and $75 \%$ compared to those from LW class $55 \%$. The calving rate of heifers was not high because of the biological and economic efficiency of production systems, especially for heifers from class $55 \%$, and this rate was even lower than average values obtained in Rio Grande do Sul for heifers mated for the first time at 36 months of age, with a pregnancy rate of 55-65\% (CARVALHO et al., 2006).

The calving rate results indicate that in situations of low animal performance in the breeding phase, especially close to mating, LW of up to $70 \%$ is insufficient to achieve reproductive rates that promote higher biological efficiency. This result is due to animal performance in the phases that preceded the beginning of mating, especially from 18 to 24 months, considering that these phases presented the most significant difference in LW gain in the present study. An unfavorable metabolic condition caused by low nutrient intake reduces the concentration of glucose, insulin, and insulin-like growth factor (IGF-I), compromising the secretion of hypothalamic-pituitary and gonadotrophins in ovarian cells (WHITE et al., 2007; BARCELLOS et al., 2014).

Another important factor that explains the low reproductive performance of heifers, especially those from LW class $55 \%$, is genetic composition, characterized by a higher percentage of zebu (Nelore) 
breed without the participation of British breeds. In this respect, Barcellos et al. (2014) observed that Nellore heifers had delayed puberty, and higher LW gains were necessary during the growth phase to reduce the age at puberty. At present, approximately $80 \%$ of the herd of Brazil is composed of zebu cattle, of which $90 \%$ are Nellore (EMBRAPA, 2016). In regions of subtropical climate, the percentage of European breeds, especially of British origin, is higher. Other studies suggest the possibility of reducing the weight at first mating to values close to $50 \%$ of adult weight for herds derived from the rotational crossbreeding of Gelbvieh, Simmental, Charolais, Red Poll, Angus, and Hereford, which are not zebuine breeds (FUNSTON; DEUTSCHER, 2004; MARTIN et al., 2008; ROBERTS et al., 2009b; FUNSTON; LARSON, 2011; LARDNER et al., 2014; TRINDADE JUNIOR et al., 2015).

The weight of pregnant heifers at age 24 months was distinct between the three LW classes, corresponding to $56 \%, 63 \%$, and $73 \%$ of for LW classes $55 \%, 65 \%$, and $75 \%$, respectively (Table 3 ). These values are similar to the average LW at 24 months for all evaluated heifers (pregnant + nonpregnant), demonstrating that pregnancy variations within each LW class were associated with factors other than weight, including the rate of LW gain before and during the first mating.
The weight variation from 24 months to calving was positive in cows from LW classes 55\% (38 $\mathrm{kg})$ and $65 \%(25 \mathrm{~kg})$, and these values were higher than those of heifers from LW class $75 \%$ $(-7.9 \mathrm{~kg})$, indicating that, although cows from the larger LW class achieved a higher calving rate in the first reproductive year, they had less potential of weight gain under the analyzed environmental and management conditions. These results can be explained by the higher maintenance requirement of this animal group because of their higher weight at all stages of the study and maximum growth potential under the evaluated environmental conditions. Larger cows show a positive linear relationship with dry matter intake and digestible energy intake because of the higher energy requirement for maintenance (FREETLY et al., 2006). Roberts et al. (2015) found that cows subjected to high LW gain in the growth phase by using food protocols very different from the real conditions used for these animals in the adult phase in extensive production systems demonstrated the greater difficulty of animal adaptation in view of the larger body size, compromising reproductive performance and longevity in the breeding herd.

Table 3. Development of cow in the second reproductive year cows of different weight classes at first mating in the period from mating to calving.

\begin{tabular}{lcccc}
\hline \multirow{2}{*}{\multicolumn{1}{c}{ Variables }} & \multicolumn{3}{c}{ Live weight class } & \multirow{2}{*}{$P$} \\
\cline { 2 - 4 } & $55 \%$ & $65 \%$ & $75 \%$ & \\
\hline WPH at 24 months, $\mathrm{kg}$ & $277.8 \pm 2.8 \mathrm{c}$ & $312.1 \pm 2.7 \mathrm{~b}$ & $364.8 \pm 3.3 \mathrm{a}$ & $<0.0001$ \\
Live weight gain from the age of 24 months to calving, $\mathrm{kg}$ & $37.8 \pm 8.9 \mathrm{a}$ & $24.5 \pm 8.8 \mathrm{a}$ & $-7.9 \pm 10.5 \mathrm{~b}$ & 0.0007 \\
Weight at calving, kg & $316.1 \pm 8.6 \mathrm{~b}$ & $336.3 \pm 8.5 \mathrm{ab}$ & $356.5 \pm 8.8 \mathrm{a}$ & 0.0019 \\
CPS, points & $2.29 \pm 0.07$ & $2.34 \pm 0.07$ & $2.35 \pm 0.07$ & 0.7733 \\
Subperiod of calving, \% & $34.5 \pm 11.2$ & $58.5 \pm 11.1$ & $54.3 \pm 12.4$ & 0.1231 \\
CBM interval, days & $36.2 \pm 5.7$ & $33.4 \pm 5.6$ & $43.1 \pm 6.2$ & 0.3723 \\
CEM interval, days & $126.5 \pm 5.7$ & $124.3 \pm 5.6$ & $131.9 \pm 6.3$ & 0.5341 \\
Interval from calving to pregnancy, days & $82.4 \pm 16.9$ & $92.6 \pm 12.6$ & $106.6 \pm 11.6$ & 0.4706 \\
\hline
\end{tabular}

WPH, weight of pregnant heifers; BCS, body condition score at calving; CBM, interval from calving to the beginning of mating; CEM, interval from calving to end of mating;

a, b, c different lowercase letters on the same line indicate significant differences at a level of significance of 5\%. 
Although the animals from LW classes 55\% and $65 \%$ gained weight from 24 months until calving, the values were low considering the ideal birth weight ( $85 \%$ of adult weight) (LARSON, 2007). In this respect, a weight increase of approximately 147 , 113 , and $60 \mathrm{~kg}$ would be necessary for LW classes $55 \%, 65 \%$, and $75 \%$ respectively. In addition, the higher LW gain in cows from LW class $55 \%$ was not enough to match the weight at calving of cows from LW class $75 \%$, supporting the hypothesis that heifers from the latter class reached their maximum growth potential whereas those from the other two classes were still under development, and this process continued until the age of four years.

The animals from LW class $75 \%$ showed higher weight at calving $(356.6 \mathrm{~kg})$ than those from LW class $55 \%(316.1 \mathrm{~kg})$, and these two values were similar to that of females from LW class $65 \%$ $(336.3 \mathrm{~kg})$. The LW gain necessary to meet the $85 \%$ adult weight recommendation is $425 \mathrm{~kg}$. This difference between measured and suggested values demonstrates the difficulty in meeting weight recommendations from mating to first calving of heifers exclusively managed in natural pastures. Colazo et al. (2009) reported that nutritional deficiencies in the prepartum period results in low birth weight, promote an increase in postpartum anestrus, and decreases the number of cows cycling in the reproductive period.

The similar weight at calving between LW classes $55 \%$ and $60 \%$, although low, is in line with the tendency found by Funston and Deutscher (2004), wherein the calving weight of cows from LW class $55 \%(415 \mathrm{~kg})$ was similar to that of cows from LW class $60 \%(421 \mathrm{~kg})$. These authors indicated that cows from LW class 55\% regained weight compared to animals from LW class $60 \%$ during gestation because of compensatory mechanisms and factors related to the lower nutritional requirement of these animals due to lower weight.

The weight at mating did not affect the BCS at calving. The difference in weight at age 24 months and at the end of the first mating disappeared at calving because of the performance of heifers during pregnancy, considering that heifers from LW class $75 \%$ had worse performance. The advantages of mating heifers with larger weight is the possibility of storing energy reserves for critical nutritional periods, such as winter. However, although the higher weight at 24 months of age was reflected in the BCS at first mating for LW classes $55 \%$ and $75 \%$, the increased weight was not maintained until calving.

The calving subperiod, which represented the percentage of heifers that calved in the first half of the calving season, was similar between the LW classes. It was expected that weight might affect this variable because age at puberty is affected by weight (ENDECOTT et al., 2013); however, this result was not observed in the present study. At least $70 \%$ of heifers should conceive at first mating because the likelihood of calving in the next mating season is increased and the calving interval is decreased (CUSHMAN et al., 2013). Approximately 50\% of heifers were born after the first half of the calving season, which directly affected the pregnancy rate, especially for heifers with low weight and BCS at calving, whose cumulative pregnancy rate was decreased.

The interval from calving to the beginning or end of mating was similar between the LW classes. Longer intervals from calving to mating are desirable because cows have more time to recover and start reproductive activities. Grecellé et al. (2006) observed that late-calving heifers in the calving season tended to maintain and exacerbate this behavior over subsequent years and present delayed calving in the next season. These authors indicated that every 10 additional days on the Julian date of delivery decreased the cumulative pregnancy rate by $11 \%$.

The interval from calving to pregnancy followed the same trend of the interval from calving to the beginning and/or end of mating and was similar 
between the LW classes. The observed values were 82, 93, and 107 days for LW classes $55 \%, 65 \%$, and $75 \%$, respectively.

The weight of calves at birth and at weaning was similar between the LW classes at mating (Table 4). Early weaning may have affected this result because interruption of lactation may prevent the effect of weight at mating on calf weight at weaning (75 days).

The LW gain from calving to weaning was higher in cows from LW class 55\% $(0.116 \mathrm{~kg} /$ day $)$ than in animals from LW class $65 \%(-0.033 \mathrm{~kg} /$ day $)$, and these values were similar to those of heifers from LW class $75 \%(0.082 \mathrm{~kg} /$ day $)$. This result may be due to the growth stage of heifers because, according to Funston et al. (2012), heifers subjected to food restriction in the growth phase, when in the second reproductive year, allocate more energy to growth than for calf development. Although there were no significant differences in weight at weaning, this hypothesis and the fact that the smaller size of heifers from LW class 55\% may have resulted in less energy for maintenance (FREETLY et al., 2006) may justify the differences in animal performance at calving, weaning, and from the age of 24 months to calving.

The weight at weaning maintained the same trend of weight at calving so that animals from LW class $75 \%$ showed higher values $(359 \mathrm{~kg})$ than those from classes $55 \%(336 \mathrm{~kg})$ and $65 \%(332 \mathrm{~kg})$.

Table 4. Production of calves and pregnancy rate of cows in the second reproductive year from different live weight classes at first mating.

\begin{tabular}{lcccc}
\hline \multirow{2}{*}{\multicolumn{1}{c}{ Variables }} & \multicolumn{3}{c}{ Live weight class } & \multirow{2}{*}{ P } \\
\cline { 2 - 4 } & $55 \%$ & $65 \%$ & $75 \%$ & 0.6257 \\
LWCB, kg & $29.8 \pm 1.5$ & $31.4 \pm 1.3$ & $30.9 \pm 1.5$ & 0.5085 \\
LWCW, kg & $80.9 \pm 3.5$ & $83.3 \pm 3.6$ & $85.6 \pm 3.7$ & 0.0217 \\
LWGCW, kg & $0.116 \pm 0.06 \mathrm{a}$ & $-0.033 \pm 0.05 \mathrm{~b}$ & $0.082 \pm 0.05 \mathrm{ab}$ & 0.0370 \\
LWHW, kg & $336.2 \pm 9.9 \mathrm{ab}$ & $331.9 \pm 9.9 \mathrm{~b}$ & $359.4 \pm 9.8 \mathrm{a}$ & 0.8237 \\
Cumulative pregnancy rate, \% & $41.6 \pm 13.1$ & $42.1 \pm 13.9$ & $50.4 \pm 13.8$ & 0.8828 \\
LWGWEM, kg & $0.212 \pm 0.29$ & $0.357 \pm 0.29$ & $0.280 \pm 0.30$ & 0.0006 \\
Weight in the second mating, kg & $344.9 \pm 10.6 \mathrm{~b}$ & $341.8 \pm 10.7 \mathrm{~b}$ & $381.1 \pm 10.5 \mathrm{a}$ & 0.0078 \\
BCSSM, points & $2.81 \pm 0.07 \mathrm{a}$ & $2.72 \pm 0.06 \mathrm{a}$ & $2.54 \pm 0.06 \mathrm{~b}$ & \\
\hline
\end{tabular}

LWCB, live weight of calves at birth $(\mathrm{kg})$; LWCW, live weight of calves at weaning $(\mathrm{kg})$; LWGCW, live weight gain from calving to weaning (kg/day); LWHW, live weight of heifers at weaning $(\mathrm{kg})$; LWGWEM, live weight gain from weaning to the end of mating (kg/day); BCSSM, body condition score in the second mating (points);

${ }^{a, b, c}$ different lowercase letters on the same line indicate significant differences at a level of significance of $5 \%$.

The average daily LW gain from weaning to the end of mating was not significantly different between the LW classes, corresponding to 0.212 , 0.357 , and $0.280 \mathrm{~kg} \mathrm{day}^{-1}$ for classes $55 \%, 65 \%$, and $75 \%$, respectively, and the weight differences at weaning were maintained until the end of mating. Furthermore, the weight of females from LW class $75 \%$ was higher than that of females from classes $55 \%$ and $65 \%$, and the values of the latter two were similar. The heifers from LW classes 55\% and 65\% showed similarities, which agrees with the results of Funston et al. (2012) and Lardner et al. (2014) for heifers from LW classes 55\% and $60 \%$. VAZ et al. (2012) found no significant differences in the performance of first-calf heifers of genotypes similar to those of the present study subjected to different levels of supplementation at first mating. The pregnancy rates in the second reproductive year 
were similar in both studies regardless of the animal management strategy at first mating.

The pregnancy rate of first-calf heifers was similar between the LW classes because of the similarity in the pre- and postpartum performance of cows. The higher reproductive performance was expected in the second mating in females from larger LW classes because of the higher development achieved in the first mating; however, this result was not observed. This fact is associated with the low performance of heifers, especially during pregnancy, and the lower LW of heifers from class $55 \%$ was compensated for by increasing animal performance in the development phases after first mating.

The pregnancy rates were $42 \%, 42 \%$, and $50 \%$ in LW classes $55 \%, 65 \%$, and $75 \%$; respectively. These values are higher than those reported in Rio Grande do Sul (6-15\%) (GOTTSCHALL; LOBATO, 1996) but are low considering the need for higher biological and economic efficiency of production systems, especially because all evaluated heifers were subjected to early weaning, for which rates $>90 \%$ were expected. Low weight and low BCS at calving caused by low pregnancy performance together with the high percentage of late-calving heifers in the calving season justify the low cumulative pregnancy rates and indicates the need to develop protocols that can be implemented in several production systems in Brazil, including reducing the gestational period of heifers and improving the nutritional status of cows during pregnancy by using improved or cultivated natural pastures, and the latter approach has long been discussed in the scientific community in Brazil. It is evident that improving the performance of heifers in the growth phase and using technologies such as early weaning for cows in the second reproductive year may not significantly improve this parameter.

The higher LW gain from calving to weaning in heifers from LW class 55\% compared to that of heifers from class $65 \%$ did not significantly affect the cumulative pregnancy rate. This result combined with similar animal performance after weaning justifies the similar pregnancy rates between the evaluated groups. Grecellé et al. (2006) observed that the combined effects of weight at first mating, BCS, Julian day of calving, and weight gain in the mating period triggered reproductive responses. The pregnancy rate was expected to increase because these variables were similar between the LW classes.

Although adult weight at the end of mating showed a trend similar to that of calving weight, the $\mathrm{BCS}$ at the end of the second mating was higher in females from LW classes 55\% and 65\% compared to those from LW class $75 \%$. It is possible that most of the weight gained by cows in the second reproductive year from the latter LW class at birth was primarily allocated to muscle development because of their larger body size (due to the higher growth rate in the breeding phase) and low animal performance during pregnancy, whereas animals with lower LW (55\% and 65\%) may have allocated most energy resources to the deposition of fat tissue.

\section{Conclusions}

Differences in animal performance in the growth phase affect heifer weight at 24 months of age and the pregnancy rate, especially when weight gains at first mating are low.

The reduction in the weight of heifers at first mating to less than $65 \%$ of adult weight compromises reproductive performance. Moreover, this characteristic may be advantageous during pregnancy by increasing the adaptability to unfavorable feeding conditions but does not significantly improve the cumulative pregnancy rate.

Achieving weight gains higher than $65 \%$ of adult weight represents a promising reproductive strategy for heifers. Nonetheless, nutritional care during pregnancy is necessary because of the higher 
development of animals subjected to this strategy.

Heifer weight at first mating does not strongly affect calving weight and weaning weight.

Regardless of the weight at first mating, heifers grazing exclusively on natural pastures during pregnancy have lower body weight and BCS, which adversely affects the cumulative pregnancy rate independently of short-term calf removal.

\section{References}

ALLEN, C. C.; ALVES, B. R. C.; LI, X.; TEDESCHI, L. O.; ZHOU, H.; PASCHAL, J. C.; RIGSS, P. K.; BRAGA-NETO, U. M.; KEISLER, D. H.; WILLIAMS, G. L.; AMSTALDEN, M. Gene expression in the arcuate nucleus of heifers is affected by controlled intake of high and low-concentrate diets. Journal of Animal Science, Champaign, v. 90, n. 7, p. 2222-2232, 2012.

ALVARES, C. A.; STAPE, J. L.; SENTElHAS, P. C.; MORAES, G. J. L. de; SPAROVEK, G. Köppen's climate classification map for Brazil. Meteorologische Zeitschrift, Stuttgart, v. 22, n. 6, p. 721-728, 2013.

BARCELLOS, J. O. J.; PEREIRA, G. R.; DIAS, E. A.; MCMANUS, C.; CANELLAS, L.; BERNARDI, M. L.; TAROUCO, A.; PRATES, E. R. Higher feeding diets effects on age and live weight gain at puberty in crossbred Nelore $\times$ Hereford heifers. Tropical Animal Health, Edinburgh, v. 46, n. 6, p. 953-960, 2014.

CARVALHO, P. C. F.; FISHER, V.; SANTOS, D. T.; RIBEIRO, A. M. L.; QUADROS, F. L. F.; CASTILHOS, Z. M. S.; POLI, C. H. E. C.; MONTEIRO, A. L. G.; NABINGER, C.; GENRO, T. C. M.; JACQUES, A. V. A. Animal production in bioma southern grasslands. In: Brazilian Journal Animal Science, 2006, João Pessoa. Anais... João Pessoa, 2006. p. 156-202.

CICCONET, N.; ALBA, J. M. F.; SPIRONELLO, R. L.; CUNHA, H. Mapping Eragrostis plana Ness (Grass Lovegrass) by means of orbital images. Revista do Departamento de Geografia - USP, São Paulo, v. 29, p. 20-33, 2015.

COLAZO, M. G.; HAYIRLI, A.; DOEPEL, L.; AMBROSE, D. J. Reproductive performance of dairy cows is influenced by prepartum feed restriction and dietary fatty acid source. Journal Dairy Science, Champaign, v. 92. n. 6, p. 2562-2571, 2009.

COOKE, R. F.; ARTHINGTON, J. D.; ARAUJO, D. B.; LAMB, G. C.; EALY, A. D. Effects of supplementation frequency on performance, reproductive, and metabolic responses of Brahman-crossbred females. Journal of Animal Science, Champaign, v. 86, n. 9, p. 2296-2309, 2008.

CUSHMAN, R. A.; KILL, L. K.; FUNSTON, R. N.; MOUSEL, E. M.; PERRY, G. A. Heifer calving date positively influences calf weaning weights through six parturitions. Journal of Animal Science, Champaign, v. 91, n. 9, p. 25 4486-4491, 2013.

EBORN, D. R.; CUSHMAN, R. A.; ECHTERNKAMP, S. E. Effect of postweaning diet on ovarian development and fertility in replacement beef heifers. Journal of Animal Science, Champaign, v. 91, n. 9, p. 4168-4179, 2013.

EMPRESA BRASILEIRA DE PESQUISA AGROPECUÁRIA - EMBRAPA. Papel do Zebu na pecuária de corte brasileira. Brasília, 2016. Disponível em: $\quad<$ https://www.embrapa.br/busca-de-noticias/-/ noticia /9523901/artigo-papel-do-zebu-na-pecuaria-decorte-brasileira >. Acesso em: 01 oct. 2019.

ENDECOTT, R. L.; FUNSTON, R. N.; MULLINIKS, T.; ROBERTS, A. J. Joint alpharma-beef species symposium: implications of beef heifer development systems and lifetime productivity. Journal of Animal Science, Champaign, v. 90, n. 3, p. 1329-1335, 2013.

FARIAS, G. D.; CERDOTES, L.; VAZ, R. Z.; RESTLE, J.; BITENCOURT, M. M.; ALVES FILHO, D. C.; BRONDANI, I. L. Biological efficiency of Charolais beef cows of different body sizes. Semina: Ciencias Agrárias, Londrina, v. 39, n. 4, p. 1737-1748, jul./ago. 2018

FREETLY, H. C.; NIENABER, J. A.; BROWNBRANDL, T. Partitioning of energy during lactation of primiparous beef cows. Journal of Animal Science, Champaign, v. 84, n. 8, p. 2157-2162, 2006.

FUNSTON, R. N.; DEUTSCHER, G. H. Comparison of target breeding weight and breeding date for replacement beef heifers and effects on subsequent reproduction and calf performance. Journal of Animal Science, Champaign, v. 82, n. 8, p. 3094-3099, 2004.

FUNSTON, R. N.; LARSON, D. M. Heifer development systems: dry-lot feeding compared with grazing dormant winter forage. Journal of Animal Science, Champaign, v. 89, n. 5, p. 1595-1602, 2011.

FUNSTON, R. N.; MARTIN, J. L.; LARSON, D. M.; ROBERTS, A. J. Physiology and endocrinology symposium: nutritional aspects of developing replacement heifers. Journal of Animal Science, Champaign, v. 90, n. 4, p. 1166-1171, 2012.

GASSER, C. L.; BURKE, C. R.; MUSSARD, M. L.; BEHLKE, E. J.; GRUM, D. E.; KINDER, J. E.; DAY, 
M. L. Induction of precocious puberty in heifers II: Advanced ovarian follicular development. Journal of Animal Science, Champaign. v. 84, n. 8, p. 2042-2049, 2006.

GOTTSCHALL, C. S.; LOBATO, J. F. P. Reproductive performance of primiparous beef cows on three stocking rates on natural pasture. Brazilian Journal Animal Science, Viçosa, v. 25, n. 1, p. 46-57, 1996.

GRECELLÉ, R. A.; BARCELLOS, J. O. J.; BRACCINI NETO, J.; COSTA, E. C. da; PRATES, E. R. Pregnancy rate of crossbred Nellore-Hereford cows in subtropical conditions under feeding restriction. Brazilian Journal of Animal Science, Viçosa, v. 35, n. 4, p. 1423-1430, 2006.

LARDNER, H. A.; DAMIRAN, D.; HENDRICK, S.; LARSON, K.; FUNSTON, R. Effect of development system on growth and reproductive performance of beef heifers. Journal of Animal Science, Champaign, v. 92, n. 7, p. 3116-3126, 2014.

LARSON, R. Heifer development: reproduction and nutrition. Veterinary Clinics of North America: Food Animal Practice, Philadelphia, v. 23, n. 1, p. 53-68, 2007.

MARTIN, J. L.; CREIGHTON, K. W.; MUSGRAVE, J. A.; KLOPFEINSTER, T. J.; CLARK, R. T. Effect of prebreeding body weight or progestin exposure before breeding on beef heifer performance through the second breeding season. Journal of Animal Science, Champaign, v. 86, n. 2, p. 451-459, 2008.

NATIONAL RESEARCH COUNCIL - NRC. Nutrients requeriments of beef cattle. $7^{\text {th }}$ ed. Washington National Academy, 1996. 244 p.

PATTERSON, D. J.; PERRY, R. C.; KIRACOFE, G. H.; BELLOWS, R. A.; STAIGMILLER, R. B.; CORAH, L. $\mathrm{R}$. Management considerations in heifer development and puberty. Journal Animal Science, Champaign, v. 70, n. 12 , p. 4018-4035, 1992.

ROBERTS, A. J.; GEARY, T. W.; GRINGS, E. E.; WATERMAN, R.; MACNEIL, M. D. Reproductive performance of heifers offered ad libitum or restricted access to feed for a 140-d period after weaning. Journal of Animal Science, Champaign, v. 87, n. 9, p. 3043-3052, 2009a.
ROBERTS, A. J.; GRINGS, E. E.; MACNEIL, M. D.; WATERMAN, R. C.; ALEXANDER, L. Implications of going against the dogma of feed them to breed them. Proceedings, Western Section. American Society of Animal Science, Champaign, v. 60, p. 85-88, 2009 b.

ROBERTS, A. J.; PETERSEN, M. K.; FUNSTON, R. N. Beef species symposium: can we build the cowherd by increasing longevity of females? Journal of Animal Science, Champaign, v. 93, n. 9, p. 4235-4243, 2015.

SOUZA, A. N. M.; ROCHA, M. G.; ROSO, D.; PÖTTER, L.; ROSA, A. T. N.; ILHA, G. F.; CONFORTIN, A. C. $\mathrm{C}$. Productivity and reproductive performance of grazing beef heifers bred at 18 months of age. Brazilian Journal of Animal Science, Viçosa, v. 41, n. 2, p. 306-313, 2012.

TRINDADE JUNIOR, G.; SILVA, R. R.; CARVALHO, G. G. P.; SILVA, F. F.; NEGRÃO, J. A.; BARROSO, D. S.; DIAS, D. L. S.; COSTA, P. B. Ganho compensatório de novilhas mestiças suplementadas em pastagens sob avaliação do perfil hormonal e parâmetros sanguíneos. Semina: Ciências Agrárias, Londrina, v. 36, n. 3, p. 1481-1494, maio/jun. 2015.

VAZ, R. Z.; RESTLE, J.; VAZ, M. B.; PASCOAL, L. L.; VAZ, F. N.; BRONDANI, I. L.; ALVES FILHO, D. C.; NEIVA, J. N. M. Performance of beef heifers until calving receiving different levels of supplementation during the breeding season, at 14 months of age. Brazilian Journal of Animal Science, Viçosa, v. 41, n. 3, p. 797-806, 2012.

WHITE, F. J.; RUBIO, I.; LENTS, C. A.; CICCIOLI, N. H.; SPICER, L. J. Effect of days after calving on insulinlike growth factor-I, insulin-like growth factor binding proteins, progesterone, androstenedione, estradiol, and aromatase mRNA in dominant follicles of postpartum beef cows. Animal Reproduction Science, Manchester, v.108, n. 3-4, p. 364-374, 2007.

WILTBANK, J. N.; GREGORY, K. E.; SWIGER, L. A.; INGALLS, J. E.; ROTHLISBERGER, J. A.; KOCH, R. M. Effects of heterosis on age and weight at puberty in beef heifers. Journal Animal Science, Champaign, v. 25, n. 3, p. 744-751, 1966. 